\title{
Genotoxic Changes in Herring from the Southern Baltic Sea
}

\author{
Karolina Gębka, Tamara Zalewska*, Anna Apanel \\ Institute of Meteorology and Water Management, National Research Institute, Gdynia, Poland
}

Received: 18 October 2018

Accepted: 22 May 2019

\begin{abstract}
A micronucleus test is a common test used as a biological indicator reflecting environmental genotoxicity caused by some of the hazardous substances' presence, and due to this it is recommended as one of the indicators for marine environmental status assessment. To determine the status of the environment, herring blood samples were collected in 2014-2017 in the southern Baltic Sea area at seven fishing grounds. The conducted analysis revealed that there is no significant correlation between the number of micronuclei in erythrocytes and sampling locations each year. This could be a result of a similar chemical status of the assessed areas as well as similar physico-chemical characteristics, but also the individual condition of the examined fish has to be taken into account as well as the their size parameters (length and weight). Statistical analysis showed statistically significant differences between the results over the years of research. The highest median values in all locations occurred in 2017, in which they were in the range of $0.57-1.37$, probably as a result of longer lengths. The threshold value was exceeded in 2016 and 2017 in all locations, indicating inadequate status of the marine environment.
\end{abstract}

Keywords: genotoxicity, micronucleus test, herring, assessment of environment status, Baltic Sea

\section{Introduction}

All living organisms are under the pressure of expanding and developing human activity. It has been observed in the marine environment as well. One of the elements constituting a significant threat to marine ecosystems is the level of contamination of marine waters by chemical substances. Many of these chemicals are toxic. Concentrations of certain substances in the marine environment are reduced as a result of a ban on their use, as exemplified by the ban on leaded petrol or dichlorodiphenyltrichloroethane

*e-mail: tamara.zalewska@imgw.pl
(DDT), but their concentrations are still monitored [1]. However, new substances appear whose concentrations and distributions in the marine environment must be controlled due to their as yet undefined potential impact on organisms. These substances can get into marine organisms by processes of bio-accumulation and bio-magnification, but they can be deposited in sediments as well. However, due to the re-suspension and remobilization processes, these substances can be reintroduced into the water column and can be transferred in the trophic chain again [2].

Depending on the type of pollutants, their impact on organism health is different. Nowadays, when the occurrence of these compounds is in the wider perspective taking their variety into account, it is not easy to identify one substance responsible for a given 
type of harmful effect or verify one factor causing the changes occurring in marine organisms. The changes in cells can be caused by ionizing radiation, heavy metals, petrochemical products, pharmaceuticals and pesticides [3-13]. In order to undertake evidence-based preventive and remedial actions it is important to verify and characterize the ecological risks generated by the presence of hazardous substances in the marine environment. Therefore, more often next to the measurement of concentrations of hazardous substances in individual elements of the environment, steps are taken to develop and implement methods to determine in a quantitative way the impact of hazardous substances on marine organisms.

This approach is extremely important given the demands placed on individual states to restore or maintain the good environmental state of maritime areas under their jurisdiction. The Marine Strategy Framework Directive (MSFD) (2008/56/EC) serves as an example of such a legal act, according to which good environmental state has to be achieved, among others, in the field of a qualitative descriptor: "Concentrations of contaminants are at levels not giving rise to effects of pollution". Therefore, it is necessary not only to measure the concentration of chemicals, but also analyze the impact of these substances on marine organisms. To give evidence of an impact of chemical pollutants on aquatic fauna, biomarkers and methods for assessing the influence of hazardous substances on chosen organisms are used. Frequently, they are included in the monitoring programs and they are recommended by the Regional Sea Convention to determine the chemical substances not previously detected as a threat and to verify the areas of decreased environmental quality [14].

For consideration of eco-toxicants and its influence, fish seem to be the most suitable. Fish are the most diverse group of vertebrates and, taking into account the fact that they are one of the most popular foods for people, they have a direct impact on human health [15].

The micronucleus test is one of the most often used to estimate the cytogenetic damage caused by the negative impact of the hazardous substances [1622]. The carcinogenic properties were confirmed for substances such as aflatoxins, benzidine, chlorinated hydrocarbons [23, 24], pesticides [25] and heavy metals $[9,10]$. The number of the micronucleus originating from chromosomes or their fragments as a result of late cell division is a measure of a gene toxicity of some substances present in the environment. This micronucleus is formed at the end of the cell division processes around the chromatin elements or their whole chromosome. It is created outside of the daughter cell [26]. This test is used in a wide range of toxicology laboratories in investigations of organisms such as fish, invertebrates and amphibians. The micronucleus test is a simple, cost-effective, rapid and convenient cytogenetic effect indicator that reveals a time-integrated exposure of marine organisms to both DNA-reactive and non-DNA reactive mutagenic compounds. It was recommended within the BEEP Project [27]. This test was also recommended as one of the biological effect indicators which should be used for monitoring and assessing the environmental status of the Baltic Sea [28].

The last complex investigation of environmental genotoxicity and cytotoxicity levels in herring was conducted in the Gulf of Gdańsk and in the southern Gdańsk Basin [30]. However, the aim of this study was to analyze the potential differences in the number of aberrations (micronucleus numbers - MN (\%) in herring originating from various areas of the entire southern Baltic Sea and caught in the period from 2014 to 2017. The results formed a basis for the assessment of the status of the marine environment of the entire Polish marine areas in the aspect of the occurrence of genotoxic changes in herring. Additionally, an attempt was made to check the influence of ichthyological parameters such as mass, length and age on the number of aberrations.

\section{Experimental}

\section{Sampling of Fish Blood}

To estimate an impact of environmental contamination on the genotoxic changes in marine organisms, the samples of peripheral blood of fish (herring - Clupea harengus) were collected in different areas of the southern Baltic Sea: the Ustecko-Łebskie fishing ground Słupsk Farrow, Kołobrzesko-Darłowskie fishing ground, Bornholm fishing ground and Władysławowo fishing ground (Table 1, Fig. 1). The numbers or letters placed along some of the names of fishing grounds in the paper indicate the different geographic coordinates of the sampling place. This material was acquired in cooperation with the National Marine Fisheries Research Institute (MIR) during cruises of the $\mathrm{r} / \mathrm{v}$ Baltica using standard bottom trawls. The fish samples were acquired in 2014-2017 (November). At each location, blood samples were drawn from the caudal vein of 10-15 fish individuals. Then it was directly applied on glass slides in as thin a layer as possible. One glass slide was prepared per fish. After that the samples were air-dried.

\section{Fish Blood Samples Analysis}

To stain the blood samples, smears were covered with a 5\% Giemsa's azur eosin methylene blue solution for 30 minutes [15]. The prepared blood samples were analyzed using a microscopic method with an Olympus BX43 microscope at final magnification of $1000 \mathrm{X}$. Micronuclei (MN) were identified according to criteria adopted from [30, 31]. MN should be: (1) smaller than the main nuclei, (2) round or oval in shape, (3) not linked to the main nuclei, (4) usually have the same staining intensity (purple/navy blue), (5) should be in 


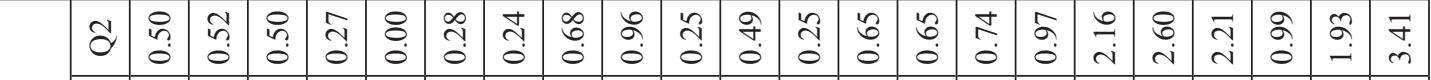

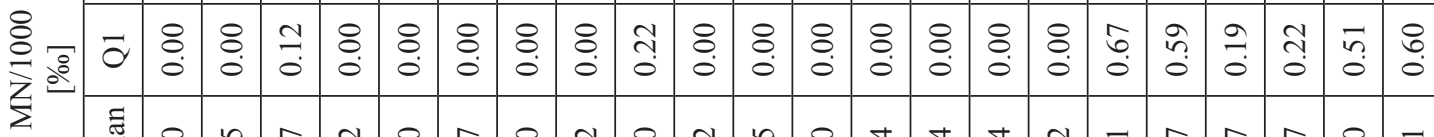

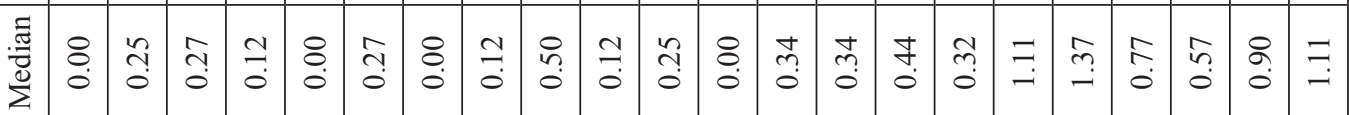

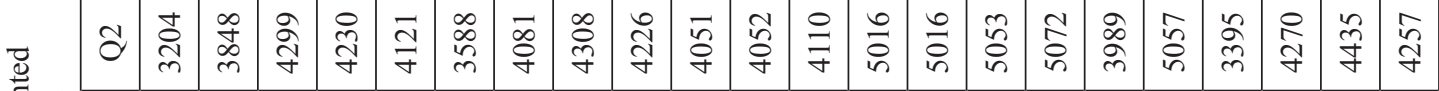

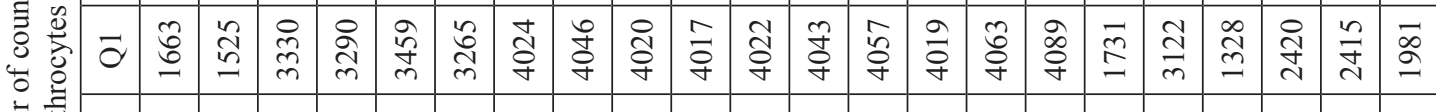

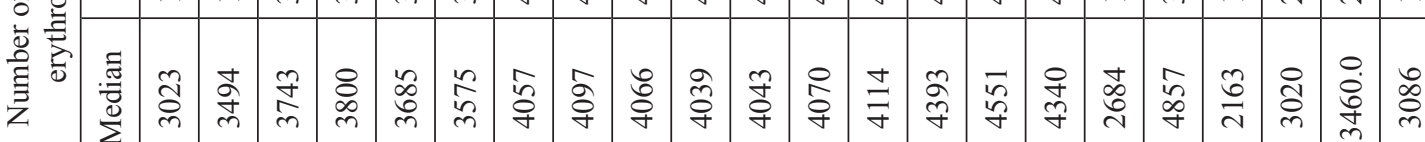

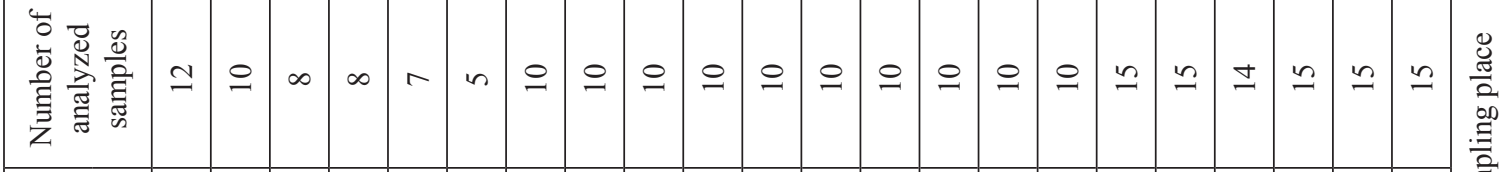

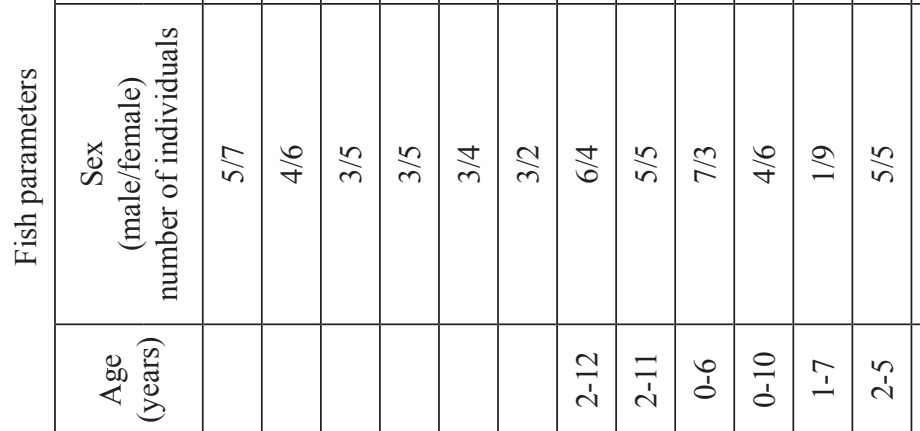

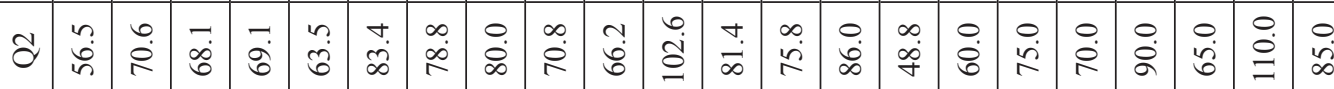

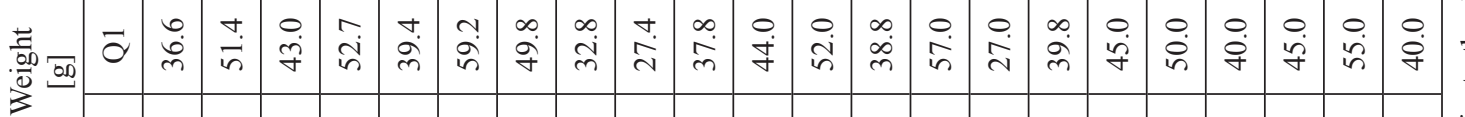

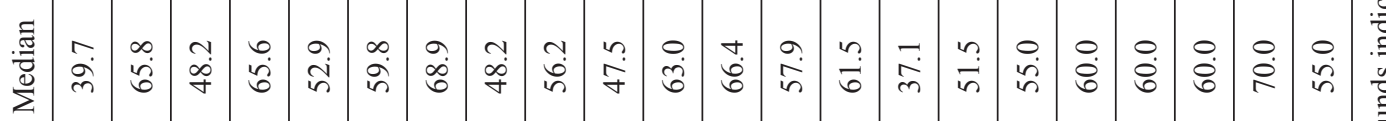

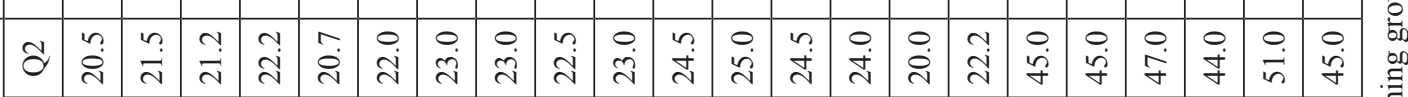

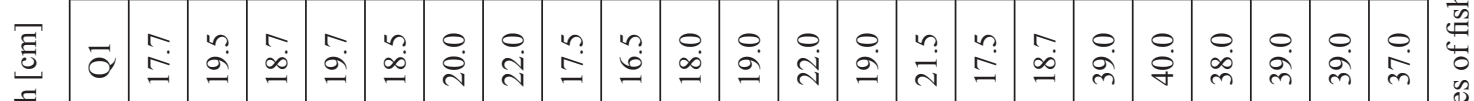

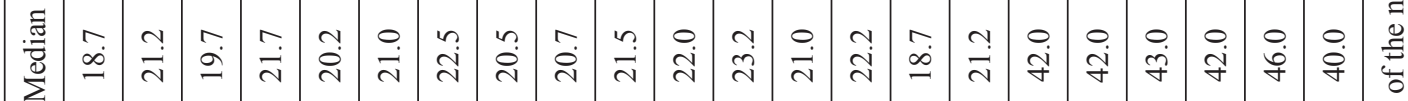




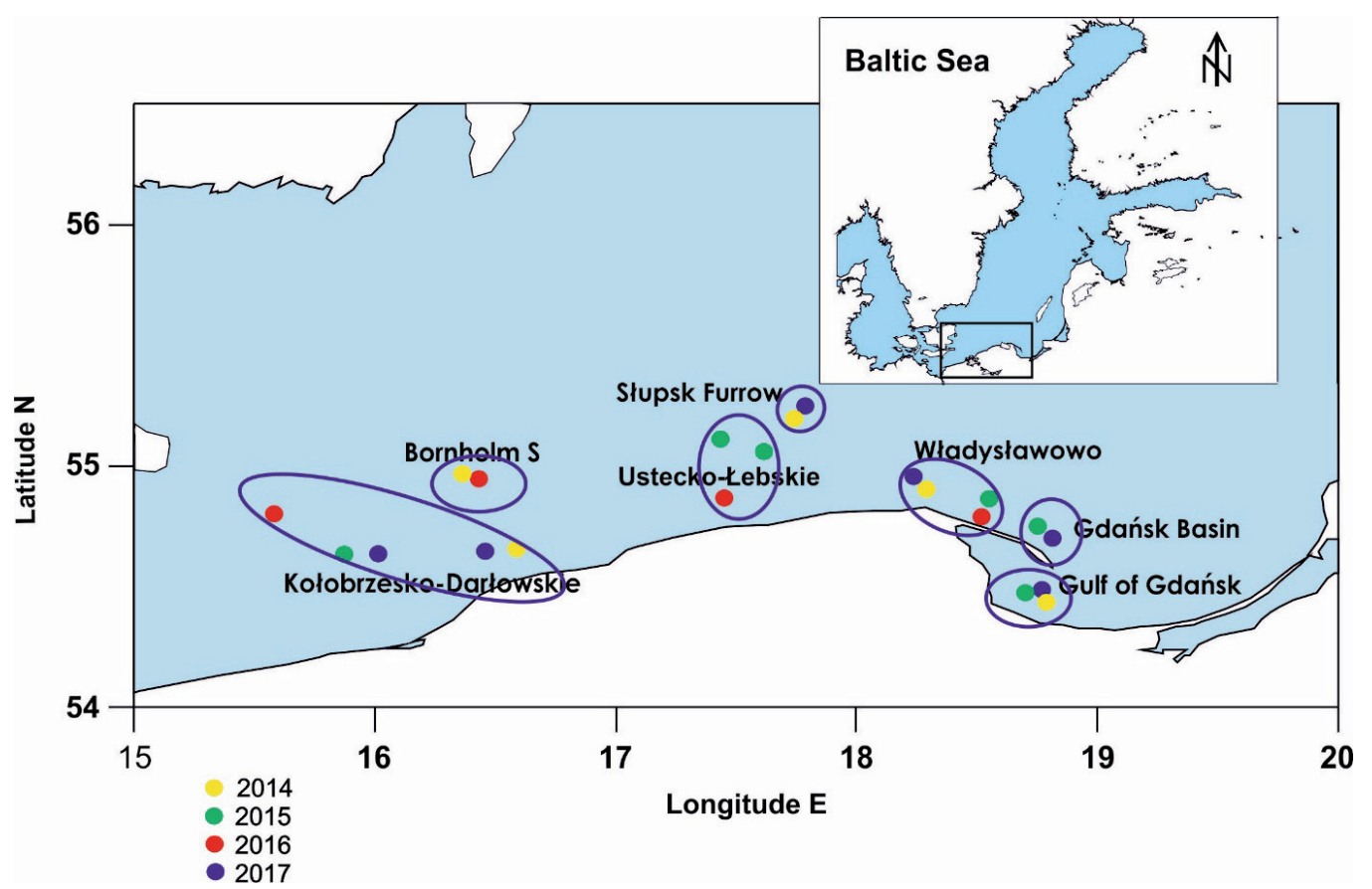

Fig. 1. Fishing grounds and sampling stations.

the same plane, and (6) the cell borders should be visible $[31,32]$. The mean number of counted erythrocytes per fish was in a range from 2203 in the Gulf of Gdańsk in the year 2017 to 4570 in Ustecko-Łebskie 2 fishing ground in the year 2016 (Table 1). The lower number of samples and lower number of counted erythrocytes at one station was the result of excluding some samples of bad quality, which can reduce the reliability of the analysis to be conducted. The amount of the identified micronuclei found on slides was recalculated on 1000 erythrocytes and used as a measure of harmful effects on a tested organism.

\section{Statistical Analysis}

Statistical tests were conducted using STATISTICA 12 software. In order to check the normal distribution of all data, the Kolomogorov-Smirnov test was used. Taking the nonparametric character of the obtained results into account, the discussion was based on the medians and quartiles, as well as the ANOVA KruskalWallis test used to verify the dependencies between the MN (\%), fishing grounds and sampling years. The significance level was 0.05 .

\section{Results and Discussion}

\section{Fish Parameters}

Sampling of blood from collected fish individuals was preceded by the determination of selected ichthyological parameters such as length, weight and age in the case of 2015. In the year 2014 the range of fish length in the particular sampling location was narrow $(16.0-23.0 \mathrm{~cm})$. The medians stayed in the range from $18.7 \mathrm{~cm}$ in the Gulf of Gdańsk to $21.7 \mathrm{~cm}$ in the Słupsk Furrow (Table 1). The differences between mass of herrings was much more visible. The higher median values (65.6 g and $65.8 \mathrm{~g}$ ) were specific in the area of Słupsk Furrow and Władysławowo fishing ground, while the lowest value $(39.7 \mathrm{~g})$ was found in the Gulf of Gdańsk. In 2015 the range of fish length was comparable to the samples taken in the previous year. The medians ranged from 20.5 in the Gdańsk Basin to 23.2 in the Kołobrzesko-Darłowskie fishing ground. The mass of taken herrings was slightly higher, for example in the Gdańsk Basin (25-111 g), but the range of medians was similar (48.2-68.9 g). The oldest fish age was 12 years. There were only two fish of small size caught in the Władysławowo and Ustecko-Łebskie fishing grounds (length about $12 \mathrm{~cm}$ and mass about $12 \mathrm{~g}$ ). It was connected to their young age, as they were less than 1 year old. In 2016, parameters - the length of a fish and its mass - in statistical terms were comparable to those in 2015. The medians of length ranged from 18.7 to $22.2 \mathrm{~cm}$, while in the case of weight the medians were within the range of $37.1 \mathrm{~cm}$ in the Bornholm area to $61.5 \mathrm{~cm}$ in Ustecko-Łebskie fishing ground. Taking the discussed parameters into account, the year 2017 differed markedly from previous years. The median fish lengths were uniform across the areas of investigation, but at the same time they were definitely higher than those observed in previous years $(42.0-46.0 \mathrm{~cm})$, while median values representing statistical distribution of weights were slightly higher than observed in previous years (55.0-70.0), which was also confirmed by a higher Q2:75\% value, especially visible in the Kołobrzesko- 
Darłowskie (110 g) and Władysławowo (90.0 g) fishing grounds.

The Spatial and Inter-Annual Differences in the Micronuclei Number in Fish Erythrocytes

In the analyzed fish blood samples, besides the micronucleus structures, other nuclear abnormalities were detected (Fig. 2). Some of them are the genotoxicity endpoints such as: micronucleus (MN), nuclear bud (NB), nuclear bud on filament (NBf) and the cytotoxicity endpoints: apoptotic (Apop) [30]. For the purpose of the assessment carried out within this study only $\mathrm{MN}$ was taken into account as a most common and operational fish condition indicator related to genotoxic impact of hazardous substances.

In 2014 the highest number of MN (\%) (represented by medians values) were found in Ustecko-Łebskie and Bornholm fishing grounds $(0.27 \%$ ) and the lowest MN (\%) were detected in KołobrzeskoDarłowskie 1 and in the Gulf of Gdańsk (0.0\%) (Table 1). The number of MN (\%) in the Słupsk Furrow was $0.12 \%$. The MN (\%o) in female blood ranged from $0.00 \%$ in the Gulf of Gdańsk, Słupsk Furrow, Bornholmskie and Kołobrzesko-Darłowskie fishing grounds to $0.29 \%$ in the Ustecko-Łebskie fishing ground (median for female in 2014: 0.0\%o). Although fewer samples of male fish were taken, the aberrations in erythrocytes were in the higher range. The lowest number of MN (\%) in male individuals was observed in the Kołobrzesko-Darłowskie fishing ground

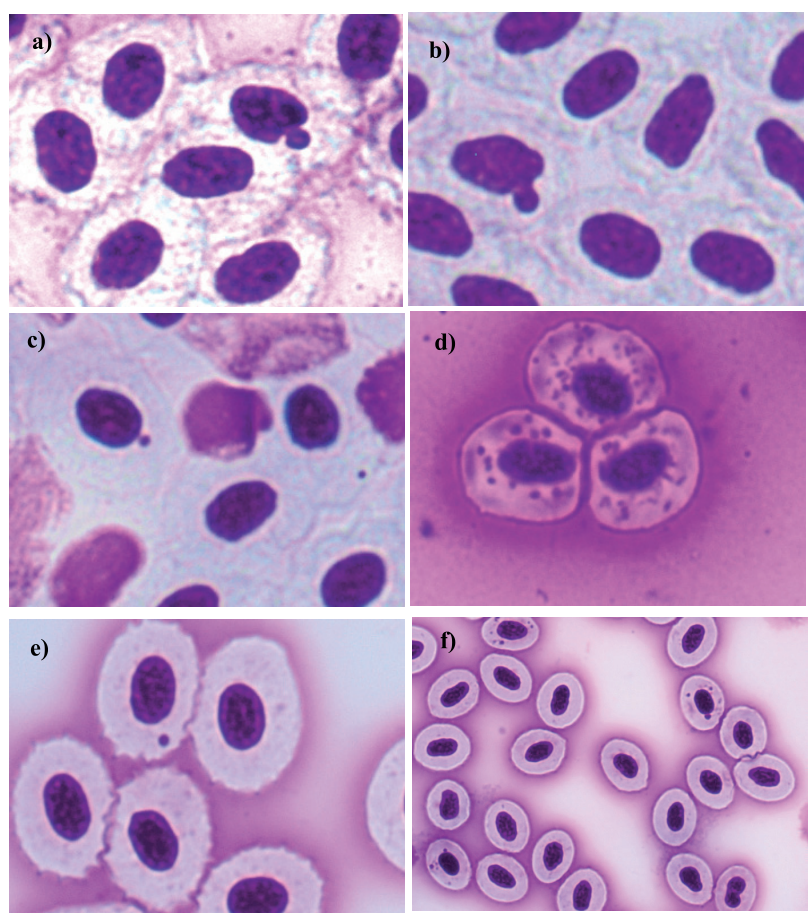

Fig. 2. Nuclear abnormalities in herring erythrocytes: $a, b)$ nuclear bud; c) nuclear bud on filament; d) apoptotic; e) micronucleus; f) micronucleus, nuclear buds and apoptic.
$(0.00 \%)$. Similar values $(0.24-0.28 \%)$ were noted in Słupsk Furrow, Ustecko-Łebskie and Bornholm areas and the higher number of MN (\%) was found in Władysławowo $(0.38 \%$ ) (median for male in 2014: $0.27 \%$ ).

The highest number of MN (\%o) in fish samples in 2015 was observed in Władysławowo fishing ground $(0.50 \%)$ and the lowest amount was detected in the same areas as in 2014 (Gulf of Gdańsk and KołobrzeskoDarłowskie fishing ground: $0.00 \%$ ). In the UsteckoŁebskie 1 fishing ground and in the Gdańsk Basin the MN (\%) was equal to $0.12 \%$, while in the UsteckoŁebskie 2 this parameter was $0.25 \%$. The number of MN (\%) in female ranged from $0.00 \%$ in the Gulf of Gdańsk and Kołobrzesko-Darłowskie fishing ground to $0.50 \%$ in Władysławowo fishing ground (median for female in 2015: $0.00 \%$ ). The value of MN (\%) male individuals ranged from $0.00 \%$ in the Gdańsk Basin to $0.50 \%$ in the Władysławowo area (median for male in 2015: $0.25 \%$ ).

In 2016 the number of MN (\%) was very uniform in all locations. It ranged from 0.32 to $0.34 \%$, but the values of Q2:75\% were slightly higher, which may indicate an increase of changes in fish erythrocytes compared to the years 2014 and 2015. This assumption is confirmed by higher MN (\%o) values calculated, taking into account the sex of the fish that were caught. The highest number of MN (\%o) was observed in females taken from Władysławowo fishing ground $(1.97 \%)$. In the same area in male blood the number of MN (\%) was 0.49 (\%). The same value was noticed in the Kołobrzesko-Darłowskie fishing ground. The medians of MN (\%) in females and males in 2016 were $0.57 \%$ and $0.44 \%$ respectively.

The most numerous abnormalities in herring erythrocytes was observed in 2017 compared to the previous years of research. The highest number of MN (\%) was observed in the Gdańsk Basin (1.37\%o), and a slightly lower value was detected in KołobrzeskoDarłowskie fishing ground and in the Gulf of Gdańsk $(1.11 \%)$, and the lowest in the area of Słupsk Furrow $(0.57 \%)$ ). Taking into account all fish samples, more MN (\%) was found in the male individuals than in the female ones. The amount of MN (\%o) in males ranged from $0.92 \%$ in Władysławowo fishing ground to $2.11 \%$ in the Bornholm fishing ground (median for male in 2017: 1.27\%). The median value of MN (\%) in female samples was $0.59 \%$. The lowest MN (\%) in female individuals was detected in fish taken in the Stupsk Furrow $0.31(\%)$, while the highest value was specific to Gulf of Gdańsk (0.93\%o).

Statistical analysis showed statistically significant (ANOVA Kruskal-Wallis $\mathrm{p}=0.0000$ ) differences between the years of research. In this case the length of the fish may be of particular importance. The highest change compared to previous years was detected in 2017. The number of aberrations that year was higher in all studied locations (Table 1). The relationship between the average number of MN (\%) in a given location and the 


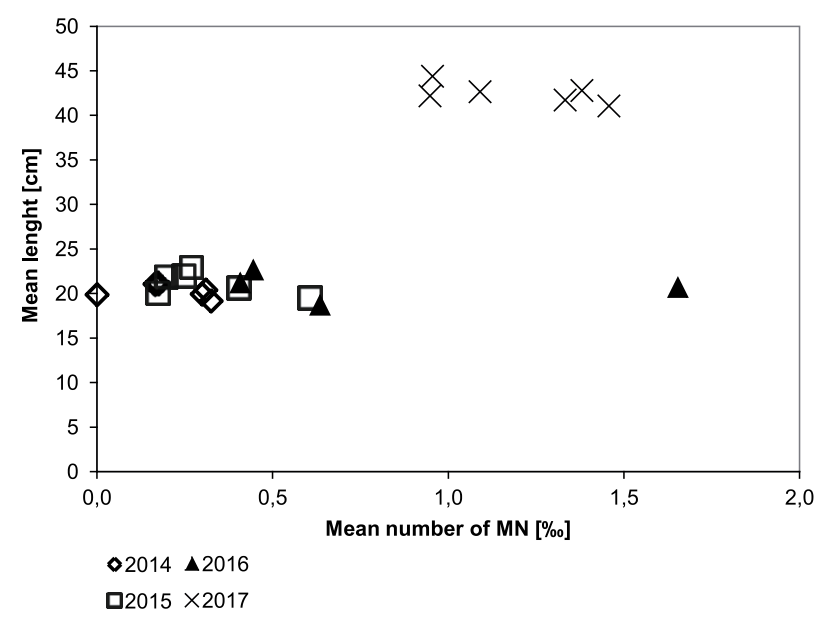

Fig. 3. Relationship between mean length of fish and number of MN (\%).

average length of fish bodies is shown in Fig. 3. In this case, the body length of the fish can be treated as a fish age proxy (although it cannot be a unified rule). In the case of older fish, the time of exposure (associated with the age) can be a factor that increases the probability for aberrations to occur. The results of the present study revealed the variability of the number of $\mathrm{MN}$, however there were no significant differences between fishing grounds in the individual years (ANOVA Kruskal-Wallis $\mathrm{p}>0.05$ ). No statistically significant differences between the number of $\mathrm{MN}$ and locations can be caused by the similar concentration of hazardous substances being of concern and similar physical and chemical conditions in the assessed areas.

Discussion of Results in Relation to the Level of $\mathrm{MN}$ in the Research and other Areas as Well as to the Contamination and Physico-Chemical Conditions of the Research Areas

Taking into account the number of MN (\%) detected in herring caught in 2014-2017, the obtained results were very similar to the results obtained in the Gulf of Gdańsk and in the southern Gdańsk Basin for herring blood samples collected in 2009-2017 [30]. The number of $\mathrm{MN}(\% \mathrm{o})$ in this area without strong frequencies (connected to the dumped munition) ranged from 0.42 to $1.65 \%$. The measurement of micronuclei in herring blood revealed the significant influence of $\mathrm{CW}$ on the aberration in fish erythrocytes, which has also been presented by [34]. The highest values of MN (\%) were observed in the simple specimen taken from the dumping site in the Polish Exclusive Economic Zone (30.0\%). Moreover, in the area of dumping sites (Bornholm Basin and Gdańsk Basin), a higher concentration of mercury was also detected [35], which can have an impact on changes in marine organisms as well [36].

Presented results were also comparable to the data obtained by Kopecka et al. [37], who indicated that the MN (\%o) in flounder (female) caught in the Gulf of Gdańsk ranged from 0.31 to $0.65 \%$. The highest value was detected in Sobieszewo and it was only one station where the differences between both sampling stations and seasons were detected. The results of the analysis carried out in flounder (Platichtys flesus) in 2011-2012, within the framework of the EU funded BEEP project, revealed no dependencies on the sampling seasons. The number of aberrations in the Gulf of Gdańsk ranged from 0.00 to $1.60 \%$ [27]. The results of $\mathrm{MN}(\%)$ in flounder and eelpout (Zoarces viviparous) in Wismar Bay were similar to the number of aberrations observed in fish from the Gulf of Gdańsk (0.1-1.6\%) [27, 32].

The micronuclei test is used also as a common bio-indicator in the North Sea offshore and Atlantic coastal waters. The value $\mathrm{MN}(\%)$ in dab (Limanda limanda) varied from $0.09 \%$ to $1.37 \%$. The highest number of aberrations was detected in the area of the Dogger Bank. The number of MN (\%o) in haddock (Melanogrammus aeglefinus) ranged from $0.03 \%$ in the reference station to $0.78 \%$ in Egersung bank [34].

The number of noticed aberrations could be caused by different chemical substances. Verification of the specific contamination influencing the damage in the erythrocytes is almost impossible in the environmental conditions taking many elements and factors that can influence the final effect into account. This is particularly difficult in the situation of synergistic interactions (cocktail effect). According to the assessment of the environment of the chosen areas (Gdańsk Basin, Bornholm Basin and Eastern Gotland Basin), the status of the environment of the southern Baltic Sea related to some of the hazardous substances' concentrations was recognized as inadequate [38]. Considering the list of substances with documented genotoxic activity [23], the most important, taking their concentrations in the Baltic Sea into account, are: ${ }^{137} \mathrm{Cs}$ representing radioactive isotopes, heavy metals: $\mathrm{Pb}, \mathrm{Cd}, \mathrm{Hg}$ and polybrominated diphenyl ethers (PBDE), polychlorinated biphenyls (PCB), organochlorine pesticides, dioxins (PCDD) and furans (PCDF).

The region of the Baltic Sea was under pressure of increased concentration of radioactive components such as ${ }^{137} \mathrm{Cs}$ and ${ }^{90} \mathrm{Sr}$ as a result of the accident of the Chernobyl nuclear power plant in 1986. However, nowadays the decreasing trend of ${ }^{137} \mathrm{Cs}$ in Baltic herring is observed. The mean activity concentration of this radioactive element in 2016 was $5.75 \mathrm{~Bq} / \mathrm{kg}$ w.w. [39], and the dose rate arising from this concentration is at the level of $0.0007 \mu \mathrm{Gy} / \mathrm{h}$, which is clearly below the screening level $10 \mu \mathrm{Gy} / \mathrm{h}$ [40] - a value based on data on dose-effect relationships for various organisms [41].

The decade-long data collection indicated a significant downward trend of $\mathrm{Hg}, \mathrm{Pb}$ and $\mathrm{Cd}$ concentrations in herring, cod and sprat from the Baltic Sea [42]. Concentrations of $\mathrm{Cd}, \mathrm{Pb}$ and $\mathrm{Hg}$ in herring muscle decreased from respectively $16 \mathrm{mg} \mathrm{kg}^{-1} \mathrm{ww}$, 
$39 \mathrm{mg} \mathrm{kg}^{-1} \mathrm{Ww}$ and $84 \mathrm{mg} \mathrm{kg}^{-1} \mathrm{ww}$, values noted in 1994 to $6.1 \mathrm{mg} \mathrm{kg}^{-1} \mathrm{ww}, 8.0 \mathrm{mg} \mathrm{kg}{ }^{-1} \mathrm{ww}$ and $22 \mathrm{mg} \mathrm{kg}^{-1} \mathrm{ww}$, level specific to 2003 [42]. However, there was a difference in heavy metal concentrations in studied species taken from different parts of the Baltic [42].

Considering organic substances, the impact of polybrominated diphenyl ethers should be taken into account. The mean concentration of the sum of 7 congeners in herring from the southern Baltic Sea was equal to $1.2 \mu \mathrm{g} \mathrm{kg}^{-1} \mathrm{Ww}$ in the period 2004-2006, and concentrations of PBDE were rather homogeneously distributed among sampling sites [43]. This means that the threshold value $0.0085 \mu \mathrm{g} \mathrm{kg}^{-1} \mathrm{WW}$ (Environmental Quality Standard according Directive 2013/39/UE) is exceeded many times. However, it should be emphasized that this value is very restrictive.

The decreasing trends were observed in the case of polychlorinated biphenyl congeners in herring caught in 1997-2006 in the southern Baltic Sea region [44]. The mean concentrations of the sum of 7 congeners changed from $25 \mu \mathrm{g} \mathrm{kg}^{-1} \mathrm{Ww}$ in 1997 to $15 \mu \mathrm{g} \mathrm{kg}{ }^{-1} \mathrm{Ww}$ in 2006 .

The same decreasing trend was also observed in the case of some of organochlorine pesticides determined in herring from the southern Baltic in 1995-2006 [45]. This concerns hexachlorocyclohexsan isomers $(\mathrm{HCH}), \mathrm{pp}$ '1,1dichloro-2,2-bis(4-chlorophenyl)ethylene (p,p' DDE) and pp'1,1-dichloro-2,2-bis(4-chlorophenyl)ethane (p,p' DDD), while concentrations of hexabromocyclododecane (HCB) and 1,1,1-trichloro-2,2-bis(4-chlorophenyl)ethane (DDT) stayed quite stable in the this period.

Chlorinated dioxins and furans (PCDD/Fs) and dioxin-like polychlorinated biphenyls, also exhibiting genotoxic action, belong to the supertoxic chemicals. Their concentrations (expressed like a WHO-TEQ) in herrings from the southern Baltic in 2002-2006, detected at the levels (0.0034-0.0051 $\mu \mathrm{g} \mathrm{kg}^{-1}$ WHO TEQ), do not exceed the permissible level set for the environment: $0.0065 \mu \mathrm{g} \mathrm{kg}^{-1}$ WHO TEQ (Environmental Quality Standard according to Directive 2013/39/UE) [46].

The frequency of micronuclei occurrence, besides the influence of chemical substances, depends on environmental and physiological parameters. The age and conditions of fish seems to be a basic factor increasing the possibilities of changes in the erythrocytes. However, the environmental parameters including access to food, temperature and salinity have an impact on aberrations as well. An increase of temperature causes an increase in the number of $\mathrm{MN}$ [33]. Taking the potential influences of temperature and salinity into account, significant differences between different years and different sub-basins were not detected. The seawater temperature in 2014 was in the range 2.0 to $21.0^{\circ} \mathrm{C}$. Similar ranges for this parameter were noted in the years: $2015\left(2.5-20.5^{\circ} \mathrm{C}\right), 2016$ $\left(3.5-20.1^{\circ} \mathrm{C}\right), 2017\left(-1.3-21.2^{\circ} \mathrm{C}\right)$. The salinity in the years cover by investigations was comparable as well: 2014 (6.4-7.8 PSU), 2015 (6.7-7.7 PSU), 2016 (6.6-7.9 PSU), 2017 (1.3-8.9 PSU) [38, 47-49].

\section{Status of the Marine Environment Based on the Micronucleus Test}

The micronucleus test can be used in the assessment of the status of the environment, also in terms of its potential genotoxicity [50-53]. To assess the status of the environment, it is necessary to set the threshold value indicating the boundary between good and inadequate conditions. In the case of the micronuclei test the most appropriate approach would be for the threshold value to indicate that exceeding a certain number of aberrations implies the exposure of a given organism to the impact

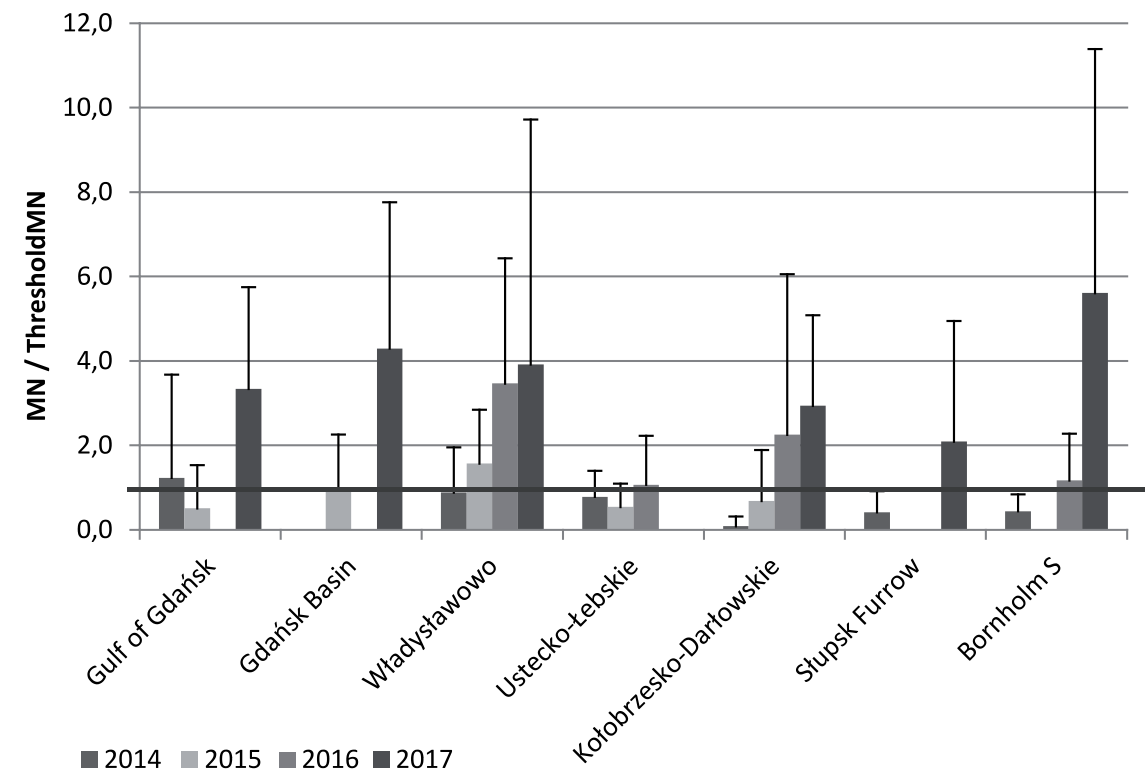

Fig. 4. Ratio of $\mathrm{MN}(\%)$ to the threshold value $\left(\mathrm{MN} / \mathrm{TV}_{\mathrm{MN}}\right)$ in the fishing grounds in 2014-2017; red line is the boundary between good and inadequate environment status. 
of factors causing them, and remaining at levels exceeding the permitted standards. Determining these limits could be only possible in laboratory conditions by exposing organisms to chemicals and testing the response in the number of micronuclei. However, such treatment can limit the impact of other factors with the synergistic effects. Due to this, a baseline and background values are often used. These values can be defined as an incidence of $\mathrm{MN}$ observed in the absence of environmental risk or before exposure to genotoxins [33]. Data of MN frequencies in samples taken from field reference sites and from organisms deployed to the uncontaminated sites have been used to set the assessment criteria which was calculated as the empirical $90 \%$ (percentile). The threshold value proposed for herring in the Baltic Sea - 0.39\%o [33] was used in this study for the southern Baltic Sea status assessment, by comparing the obtained results with threshold value.

In order to assess the status of the environment in terms of genotoxic changes in herring, the ratio of $\mathrm{MN}(\%)$ to the threshold value $\left(\mathrm{MN} / \mathrm{TV}_{\mathrm{MN}}\right)$ for each individual fish was determined and based on these mean values and standard deviations for each fishery ground in each year (Fig. 4). The value of MN/TV ${ }_{\mathrm{MN}}$ exceeding 1 indicates inadequate status.

In 2014, the threshold value was not exceeded in 5 of 6 sampling areas, which indicates that a good status of environment was achieved. The lowest value of MN/ $\mathrm{TV}_{\mathrm{MN}}$ equal to 0.1 was specific to the KołobrzeskoDarłowskie fishery ground. In the Słupsk Furrow and Bornholm $\mathrm{S}$ the calculated $\mathrm{MN} / \mathrm{TV}_{\mathrm{MN}}$ was the same (0.4), while in Ustecko-Łebskie and Władysławowo it was twice as high. In 2014, the value of $\mathrm{MN} / \mathrm{TV}_{\mathrm{MN}}$ was slightly higher than 1 only in the Gulf of Gdańsk (1.2). In 2015, the threshold value was exceeded only in the Władysławowo fishery ground $\left(\mathrm{MN} / \mathrm{TV}_{\mathrm{MN}}=1.6\right)$, while in the Gdańsk Basin $\mathrm{MN} / \mathrm{TV}_{\mathrm{MN}}$ it was equal exactly to 1. In the case of the Gulf of Gdańsk, the UsteckoŁebskie and Kołobrzesko-Darłowskie fishery grounds calculated ratio stayed in the narrow range of from 0.5 to 0.7 , indicating good status. In 2016, in all three investigated areas good status was not achieved. In the area of the Władysławowo fishing ground the value of $\mathrm{MN} / \mathrm{TV}_{\mathrm{MN}}$ (3.5) increased twice, while in the Kołobrzesko-Darłowskie fishery ground this increase was even threefold to the value 2.1. In the UsteckoŁebskie and Bornholm $\mathrm{S}$ areas the threshold value was exceeded only slightly. The values of $\mathrm{MN} / \mathrm{TV}_{\mathrm{MN}}$ were equal to 1.1 and 1.2 respectively. In 2017, good status was not achieved in any of the sampling locations, and mean values of MN (\%o) were visibly higher than threshold value, giving the ratio values in the range of 2.1 in the Ustecko--ebsko, through 4.3 in the Gdańsk Basin to 5.6 in the Bornholm S area. Relatively large standards of deviation values indicate significant differences in the $\mathrm{MN} / \mathrm{TV}_{\mathrm{MN}}$ ratios determined between individual fish.

\section{Conclusions}

1. Studies on the occurrence of micronucleus, which is a measure of genotoxic changes in fish blood erythrocytes, conducted in 2014-2017 in seven locations in the southern Baltic Sea, showed no statistically significant differences between fishing grounds in particular years.

2. At the same time, the statistical analysis showed statistically significant (ANOVA Kruskal-Wallis $\mathrm{p}=0.0000)$ differences between the years of research. The highest median values in particular locations occurred in 2017, in which they ranged 0.57-1.37. In the remaining years, they changed respectively in the following ranges: $0.00-0.27$ in 2014, 0.00-0.25 in 2015 and 0.32-0.44 in 2016, while in 2016 the study was conducted only in four areas. The higher MN (\%) values recorded in 2017 are most likely related to the larger fish length (approximately twice as long as in other years). Fish length in this case may be a proxy for the age of fish, and thus the exposure time to the action of genotoxic agents. The fish susceptibility to genotoxic changes is determined by both internal and external factors, and the last ones include concentrations of specific substances in the environment as well as temperature and salinity. As has been shown, there are no unambiguous differences in the discussed parameters between individual areas and years of research that could be unequivocally related to the observed differences in MN (\%).

3. Taking the threshold value set for MN (\%) into account, in the year 2014 the good status of the marine environment was not achieved only in the Gulf Of Gdańsk, but threshold value was exceeded only slightly. This was also the case of Władysławowo fishing ground in 2015. In 2016, the boundary between good and inadequate status was exceeded in two areas: in Władysławo fishing grounds the threshold value was exceeded over 3 times, and twice in Kołobrzesko-Darłowskie. In 2017, the highest number of MN caused the exceeding of a good state of the environment in each of the studied locations (the ratio of MN (\%) to the threshold value changed in the range 1.1 to 5.6).

\section{Acknowledgements}

This work was supported by National Fund for Environmental Protection and Water Management. Data comes from the Polish part of the Baltic Sea studies coordinated by the Chief Inspectorate of Environmental Protection 


\section{Conflict of Interest}

The authors declare no conflict of interest.

\section{References}

1. Global Sustainable Development Report (GSDR). (2015). (https://sustainabledevelopment.un.org/ globalsdreport/2015)

2. ZHANG W., LIU X., CHENG H., ZENG Y., HU Y. Heavy metal pollution in sediments of a typical mariculture zone in South China. Marine Pollution Bulletin 64, 712, 2012.

3. MARLASCA M.J., SANPERA C., RIVA M.C., SALA R., CRESPO S. Hepatic alterations and induction of micronuclei in rainbow trout (Oncorhynchus mykiss) exposed to a textile industry effluent. Histology and Histopathology 13, 703, 1998.

4. BARKA S., OUANES Z., GHARBI A., GDARA I., MOUELHI S., HAMZA-CHAFFAI A. Monitoring genotoxicity in freshwater microcrustaceans: A new application of the micronucleus assay. Mutation Research/ Genetic Toxicology and Environmental Mutagenesis, 803804, 27, 2016.

5. BARDA L., KANKAANPÄÄ H., PURINA I., BALODE M., SJÖVALL O., MERILOUTO J. Bioaccumulation of hepatotoxins - A considerable risk in the Latvian environment. Environmental Pollution, 196, 313, 2015.

6. GERBERSDORF S.U., CIMATORIBUS C., CLASS H. ENGESSER K.-H., HELBICH S. HOLLERT H., LANGE C., KRANERT M., METZGER J., NOWAK W., SEILER T.-B., STEGER K., STEINMETZ H., WIEPRECHT S., Anthropogenic Trace Compounds (ATCs) in aquatic habitats - Research needs on sources, fate, detection and toxicity to ensure timely elimination strategies and risk management. Environment International, 79, 85, 2015.

7. GUILLERMIN A.C., PEREIRA S., DELLA-VEDOVA C., HINTON T., GARNIER-LAPLACE J. Genotoxic and reprotoxic effects of tritium and external gamma irradiation on aquatic animals. Reviews of Environmental Contamination and Toxicology, 220, 67, 2012.

8. CANALEJO A., DIAZ-DE-ALBA M., GRANADOCASTRO M.D., CORDOBA F., ESPADA-BELLIDO E., GALINDO-RIANO M.D., TORRONTERAS R. Early genotoxic response and accumulation induced by waterborne copper, lead, and arsenic in European seabass, Dicentrarchus labrax. Environmental Science and Pollution Research, 23, 3256, 2016.

9. GALINDO B.A., TROILO G., CÓLUS I.M.S., MARTINEZ C.B.R., SOFIA S.H. Genotoxic effects of aluminum on the neotropical fish prochilodus lineatus. Water Air and Soil Pollution, 212, 419, 2010.

10. JOSE S., JAYESH P., MOHANDAS A., PHILIP R., BRIGHT SINGH I.S. Application of primary haemocyte culture of Penaeus monodon in the assessment of cytotoxicity and genotoxicity of heavy metals and pesticides. Marine Environmental Research 71, 169, 2011.

11. HORIBE A., ODASHIMA S., HAMASUNA N., MORITA T., HAYASHI M. Weight of contribution of in vitro chromosomal aberration assay for evaluation of pesticides: Experience of risk assessment at the Food Safety Commission of Japan. Regulatory Toxicology and Pharmacology 95, 133, 2018.

12. BOLOGNESI C., HOLLAND N. The use of the lymphocyte cytokinesis-block micronucleus assay for monitoring pesticide-exposed populations. Mutation Research 770, 183, 2016.

13. MATOS L.A., CUNHA A.C.S, SOUSA A.A., MARANHÃO J.P.R., SANTOS N.R.S., DE M.C. GONÇALVES M., DE M. DANTAS S.M.M., DE C. E SOUSA J.M., PERON A.P., CAVALCANTI CARNEIRO DA SILVA F., DE ALENCAR M. V.O.B., MD. TOREQUL ISLAM C., RAÍ PABLO SOUSA DE AGUIAR, DE C. MELO-CAVALCANTE A.A., BONECKER C.C., JUNIOR H.F.J. The influence of heavy metals on toxicogenetic damage in a Brazilian tropical river. Chemosphere 185, 852, 2017.

14. WERNERSSON A.S., CARERE M., MAGGI C., TUSIL P., SOLDAN P., JAMES A., SANCHEZ W., DULIO V., BROEG K., REIFFERSCHEID G., BUCHINGER S., MAAS H., VAN DER GRINTEN E., O'TOOLE S., AUSILI A., MANFRA L., MARZIALI L., POLESELLO S., LACCHETTI I., MANCINI L., LILJA K., LINDEROTH M., LUNDEBERG T., FJÄLLBORG B., PORSBRING T., LARSSON D.G.J., BENGTSSON-PALME J., FÖRLIN L., KIENLE C., KUNZ P., VERMEIRSSEN E., WERNER I., ROBINSON C.D., LYONS B., KATSIADAKI I., WHALLEY C., DEN HAAN K., MESSIAEN M., CLAYTON H., LETTIERI T., CARVALHO R.N., GAWLIK B.M., HOLLERT H., DI PAOLO C., BRACK W,. KAMMANN U,. KASE R. The European technical report on aquatic effect-based monitoring tools under the water framework directive. Environmental Science 27, 1, 2015.

15. BOLS N.C., BRUBACHER J.L., GANASSIN R.C., LEE L.E.J. Ecotoxicology and innate immunity in fish. Development and Comparative Immunology 25, 853, 2001.

16. GUTIÉRREZ J.M., VILLAR S., ACUÑA P.A. Micronucleus test in fishes as indicators of environmental quality in subestuaries of the Rio de la Plata (Uruguay). Marine Pollution Bulletin, 91, 518, 2015.

17. HUSSAIN B., SULTANA T., SULTANA S., MASOUD M.S., AHMED Z., MAHBOOB S. Fish ecogenotoxicology: Comet and micronucleus assay in fish erythrocytes as in situ biomarker of freshwater pollution. Saudi Journal of Biological Sciences, 25, 393, 2018.

18. ARALDI R.P., DE MELO C.T., MENDES T.B., DE SÁ JÚNIOR P.L., NOZIMA B.H.N., ITO E.T., DE CARVALHO R.F., DE SOUZA E.B., DE CASSIA STOCCO R. Using the comet and micronucleus assays for genotoxicity studies: A review. Biomedicine and Pharmacotherapy, 72, 74, 2015.

19. ARSLAN O.Ç., BOYACIOĞLU M., PARLAK H., KATALAY S., KARAASLAN M.A. Assessment of micronuclei induction in peripheral blood and gill cells of some fish species from Aliağa Bay Turkey. Marine Pollution Bulletin, 94, 48, 2015.

20. ARSLAN O.Ç., PARLAK H. Micronucleus test good biomarker for determination of genetic changes in aquatic organism. Journal of Aquatic Pollution and Toxicology, 1, $1,2017$.

21. BOLOGNESI C., HAYASHI M. Micronucleus assay in aquatic animals. Mutagenesis, 26, 205, 2011.

22. CARROLA J., SANTOS N., ROCHA M.J., FONTAINHAS-FERNANDES A., PARDAL M.A., MONTEIRO R.A., ROCHA E. Frequency of micronuclei and of other nuclear abnormalities in erythrocytes of grey mullet from the Mondego, Douro and Ave estuaries Portugal. Environmental Sciences and Research Pollution, 21, 6057, 2014. 
23. AL-SABTI K. An in vitro binucleated blocked hepatic cell technique for genotoxicity testing in fish. Mutation Research 335, 109, 1995.

24. PACHECO M., SANTOS M.A. Naphthalene and b-naphthoflavone effects on Anguilla anguilla L. hepatic metabolism and erythrocytic nuclear abnormalities. Environment International 28, 285, 2002.

25. GRISOLIA C.K., STARLING F.L. Micronuclei monitoring of fishes from Lake Paranoa, under influence of sewage treatment plant discharges. Mutation Research, 491, 39, 2001.

26. MERSCH J., BEAUVAIS M. The micronucleus assay in the zebra mussel, Dreissena polymorpha, to in situ monitor genotoxicity in freshwater environments. Mutation Research, 393, 141, 1997.

27. LEHTONEN K.K., SCHIEDEK D., KÖHLER A., LANG T., VUORINEN P.J., FÖRLIN L., BARŠIENE J., PEMPKOWIAK J., GERCKEN J. The BEEP project in the Baltic Sea: Overview of results and outline for a regional biological effects monitoring strategy. Marine Pollution Bulletin, 53, 523, 2006.

28. Development of a set of core indicators: Interim report of the HELCOM CORESET project. Part B: Descriptions of the indicators. Baltic Sea Environment Proceedings No. 129B, HELCOM 2012.

29. HELCOM core indicators: Final report of the HELCOM CORESET project. Balt. Sea Environ. Proc. No. 136 HELCOM, 2013.

30. VALSKIENE R., BARŠIENE J., BUTRIMAVIČIENE L., GRYGIEL W., STUNŽENAS V., JOKŠAS K., STANKEVIČIŪTE M. Environmental genotoxicity and cytotoxicity levels in herring (Clupea harengus), flounder (Platichthys flesus) and cod (Gadus morhua) inhabiting the Gdansk Basin of the Baltic Sea. Marine Pollution Bulletin, 133, 65, 2018.

31. FENECH M. The in vitro micronucleus technique. Mutation Research, 455, 81, 2000.

32. SCHIEDEK D., BROEG K., BARŠIENE J., LEHTONEN K.K., GERCKEN J., PFEIFER S., VUONTISJÄRVI H., VUORINEN P.J., DEDONYTE V., KOEHLER A., BALK L., SCHNEIDER R. Biomarker responses as indicator of contaminant effects in blue mussel (Mytilus edulis) and female eelpout (Zoarces viviparus) from the southwestern Baltic Sea. Marine Pollution Bulletin, 53, $387,2006$.

33. Report of the Study Group on Integrated Monitoring of Contaminants and Biological Effects (SGIMC), 1418 March 2011, Copenhagen, Denmark. ICES CM 2011/ ACOM:30.265pp., ICES, 2011.

34. BARŠIENE J., BUTRIMAVIČIENE L., GRYGIEL W., LANG T., MICHAILOVAS A., JACKŪNAS T. Environmental genotoxicity and cytotoxicity in flounder (Platichthys flesus), herring (Clupea harengus) and Atlantic cod (Gadus morhua) from chemical munitions dumpling zones in the southern Baltic Sea. Marine Environmental Research, 96, 56, 2014.

35. GEBKA K., BEŁDOWSKI J., BEŁDOWSKA M. The impact of military activities on the concentration of mercury in soils of military training grounds and marine sediments. Environmental Science and Pollution Research, 23, 23103, 2016.

36. DELLA TORRE C., PETOCHI T., CORSI I., DINARDO M.M., BARONI D., ALCARO L., FOCARDI S., TURSI A., MARINO G., FRIGERI A., AMATO E. DNA damage, severe organ lesions and high muscle levels of As and $\mathrm{Hg}$ in two benthic fish species from a chemical warfare agent dumping site in the Mediterranean Sea. Science of the Total Environment, 408, 2136, 2010.

37. KOPECKA J., LEHTONEN K.K., BARŠIENE J., BROEG K., VUORINEN P.J., GERCKEN J., PEMPKOWIAK J. Measurements of biomarker levels in flounder (Platichthys flesus) and blue mussel (Mytilus trossulus) from the Gulf of Gdańsk (southern Baltic). Marine Pollution Bulletin, 53, 406, 2006.

38. KRZYMIŃSKI W. (ed.) Assessment of the environmental status of the Polish Baltic Sea areas based on monitoring data from 2017 against the background of the decade 2007-2016. Inspekcja Ochrony Środowiska - Biblioteka Monitoringu Środowiska, Warszawa, 2018 [In Polish].

39. ZALEWSKA T., SUPLIŃSKA M. Fish pollution with anthropogenic ${ }^{137} \mathrm{Cs}$ in the southern Baltic Sea. Chemosphere, 90, 1760, 2013.

40. Thematic Assessment of the Radioactive Substances in the Baltic Sea, 2011-2015. Baltic Sea Environment Proceedings No. 151, HELCOM 2018.

41. ANDERSON P., GARNIER-LAPLACE, J. BERESFORD N.A., CPPLESTONE D., HOWARD B.J., HOWE P., OUGHTON D., WHITEHOUSE P. Protection of the environment from ionizing radiation in a regulatory context (protect): proposed numerical benchmark values. Journal of Environmental Radioactivity, 100, 1100, 2009.

42. POLAK-JUSZCZAK L. Temporal trends in the bioaccumulation of trace metals in herring, sprat, and cod from the southern Baltic Sea in the 1994-2003 period. Chemosphere 76, 1334, 2009.

43. SZLINDER-RICHERT J., BARSKA I., USYDUS Z., GRABIC R. Polybrominated diphenyl ethers (PBDEs) in selected fish from the southern Baltic Sea. Chemosphere, 78, 695, 2010.

44. SZLINDER-RICHERT J., BARSKA I. MAZERSKI J., USYDUS Z. PCBs in fish from the southern Baltic Sea: levels, bioaccumulation features, and temporal trends during the period from 1997 to 2006. Marine Pollution Bulletin, 58, 85, 2009.

45. SZLINDER-RICHERT J., BARSKA I. MAZERSKI J., USYDUS Z. Organochlorine pesticides in fish from the southern Baltic Sea: levels, bioaccumulation features, and temporal trends during the 1995-2006 period. Marine Pollution Bulletin, 56, 927, 2008.

46. SZLINDER-RICHERT J., BARSKA I. MAZERSKI J., USYDUS Z. Investigation of PCDD/Fs and dl-PCBs in fish from the southern Baltic Sea during the 2002-2006 period. Chemosphere, 74, 1509, 2009.

47. ZALEWSKA T., KRZYMIŃSKI W., SMOLIŃSKI SZ. (ed.) Assessment of the environmental status of the Polish Baltic Sea areas based on monitoring data from 2014 against the background of the decade 2004-2013. Inspekcja Ochrony Środowiska - Biblioteka Monitoringu Środowiska, Warszawa 2015, ISBN 978-83-61227-53-3, 5, [In Polish].

48. ŁYSIAK-PASTUSZEK E., ZALEWSKA T., KRZYMIŃSKI W., GROCHOWSKI A., (ed.) Assessment of the environmental status of the Polish Baltic Sea areas based on monitoring data from 2015 against the background of the decade 2005-2014. Inspekcja Ochrony Środowiska - Biblioteka Monitoringu Środowiska, Warszawa 2016, ISBN 978-83-61227-77-9, 5-160. [In Polish].

49. KRZYMIŃSKI W. (ed.) Assessment of the environmental status of the Polish Baltic Sea areas based on monitoring data from 2016 against the background of the decade 
2006-2015. Inspekcja Ochrony Środowiska - Biblioteka Monitoringu Środowiska, Warszawa 2017 [In Polish].WAN R., MENG F., SU E., FU W., WANG Q. Development of a classification scheme for evaluating water quality in marine environment receiving treated municipal effluent by an integrated biomarker approach in Meretrix meretrix. Ecological Indicators 93, 697, 2018.

50. DEUTSCHMANN B., KOLAREVIC S., BRACKC W., KAISAREVIC S., KOSTIC J., KRACUN-KOLAREVIC M., LISKA I., PAUNOVIC M., SEILER T.-B., SHAO Y., SIPOS S., SLOBODNIK J., TEODOROVIC I., VUKOVIC-GACIC B., HOLLERT H. Longitudinal profile of the genotoxic potential of the River Danube on erythrocytes of wild common bleak (Alburnus alburnus) assessed using the comet and micronucleus assay. Science of the Total Environment 573, 1441, 2016.
51. GHERRAS TOUAHRI H., BOUTIBA Z., BENGUEDDA W., SHAPOSHNIKOV S. Active biomonitoring of mussels Mytilus galloprovincialis with integrated use of micronucleus assay and physiological indices to assess harbor pollution. Marine Pollution Bulletin 110, 52, 2016.

52. HARIRI M., MIRVAGHEFI A., FARAHMAND H., TAGHAVI L., SHAHABINIA A.R. In situ assessment of Karaj River genotoxic impact with the alkaline comet assay and micronucleus test, on feral brown trout (Salmo trutta fario). Environmental Toxicology and Pharmacology 58, 59-69, 2018.

53. HELCOM Monitoring and Assessment Strategy, 2013. http://www.helcom.fi/Documents/Action $\% 20$ areas/ Monitoring\%20and\%20assessment/Monitoring\%20 and $\% 20$ assessment $\% 20$ strategy/Monitoring $\% 20$ and $\% 20$ assessment $\% 20$ strategy.pdf 
